\begin{tabular}{|l|l|l||}
\hline \multicolumn{2}{|c|}{ PublisherInfo } \\
\hline \hline PublisherName & $:$ & BioMed Central \\
\hline \hline PublisherLocation & $:$ & London \\
\hline \hline PublisherImprintName & $:$ & BioMed Central \\
\hline \hline
\end{tabular}

\title{
Responding to metal
}

\begin{tabular}{|l|l|l||}
\hline \multicolumn{2}{|c|}{ ArticleInfo } \\
\hline \hline ArticleID & $:$ & 3716 \\
\hline \hline ArticleDOI & $:$ & $10.1186 /$ gb-spotlight-20000704-01 \\
\hline \hline ArticleCitationID & $:$ & spotlight-20000704-01 \\
\hline \hline ArticleSequenceNumber & $:$ & 153 \\
\hline \hline ArticleCategory & $:$ & Research news \\
\hline \hline ArticleFirstPage & $:$ & 1 \\
\hline \hline ArticleLastPage & $:$ & 2 \\
\hline \hline & & RegistrationDate : 2000-07-04 \\
ArticleHistory & $:$ & OnlineDate $\quad$ 2000-07-04 \\
\hline \hline ArticleCopyright & $:$ & BioMed Central Ltd2000 \\
\hline \hline ArticleGrants & $:$ & \\
\hline \hline ArticleContext & $:$ & 130591111 \\
\hline \hline
\end{tabular}


William Wells

Email: wells@biotext.com

DNA microarrays can identify all the genes that respond to a given perturbation, but indirect effects can make the lists overwhelmingly long. Lyons et al. report in the July 5 Proceedings of the National Academy of Sciences that such a list can be narrowed down by searching for shared promoter motifs (Proc. Natl. Acad. Sci. USA 2000, 97:7957-7962). They find that up to 15\% of yeast genes change expression levels in cells deprived of zinc. But only 46 genes have both a candidate zinc-responsive element (ZRE; identified by a motif-finding algorithm) for binding the Zap1p transcriptional activator, and a higher expression level when both Zap1p is intact and zinc is low. Zinc induction by some of these promoters and their candidate ZREs is confirmed, and some of the genes give clues as to how the cell responds to a lack of zinc.

\section{References}

1. Exploring the metabolic and genetic control of gene expression on a genomic scale.

2. Proceedings of the National Academy of Sciences, [http://www.pnas.org/]

This PDF file was created after publication. 